reference to higher authority, increased collaboration between Departments with the view of avoiding overlapping of functions, a re-organization of the remaining work so as to make the minimum demands on professional qualifications, and to ensure that work not requiring such qualifications is devolved on persons less highly qualified. The report also recommends that delays in the payment of inereases of salary either as increments or as the result of promotion should be eliminated, and the immediate investigation of the alleged inadequacy of salaries paid to technical officers. The Committee regards it as fundamental that there should be a reasonable relation between the salaries paid by Government and industrial firms respectively.

\section{Agriculture in Northern Ireland}

AdDressing a meeting at Ballyclare, Northern Treland, Mr. J. F. Gordon, the Northern Ireland Minister of Labour, said that during the present year the farmers of Northern Ireland have surpassed all previous records in the production of food. They have increased land cultivation by 100 per cent, and obtained an agricultural turnover during the year of $£ 44,000,000$. After feeding the people of Northern Ireland and the troops stationed there the farmers have sent about $\$ 10,000,000$ worth of food, including $360,000,000$ eggs, to swell the larder in Great Britain. The Northern Ireland Ministry of Agriculture has pushed ahead with a scheme of potato processing plant, and it is hoped that nine factories will be completed in time to deal with the 1942 surplus crop, converting it into potato meal for animal feeding and into potato for human consumption.

\section{Depths of the Arctic Ocean}

A NOTE on some important Soviet flights in the Arctic is contained in the Polar Record of July. In March 1941 Ivan Cherevichni, and four others, flew from Moscow via Archangel, Franz Josef Land and Severnaya Zemlya to their base on Wrangel Island. Thence several flights were made to the north to investigate conditions in the least known area of the Arctic Sea. On the first flight a descent on the pack was made in lat. $81^{\circ} 2^{\prime} \mathrm{N}$., long. $180^{\circ} \mathrm{E}$., and for four days hydrographical observations were made. The ocean depth was $1,447 \mathrm{fm}$. The next flight was to lat. $78^{\circ} \mathrm{N}$., long. $176^{\circ} 40^{\prime} \mathrm{E}$., where the depth was $1,015 \mathrm{fm}$. , and the third flight was to lat $78^{\circ} \mathrm{N}$., long. $170^{\circ} \mathrm{E}$., where the depth was $1,878 \mathrm{fm}$. In the Cherevichni triangle, made by these three stations, the depths appear to be considerably less than the single sounding of Sir Hubert Wilkins in 1927 in lat. $77^{\circ} 45^{\prime} \mathrm{N}$., long. $175^{\circ} \mathrm{W}$., which was $2,830 \mathrm{fm}$. These discrepancies in depths were not expected in the Arctic Ocean. The physicist in the party found the intermediate layer of warm Atlantic water at all three stations. It will be recalled that this layer, first found by Nansen, was noted by Papanin, of the Soviet drifting polar station, some years ago. It is now fair to assume that it occurs throughout the Arctic basin.

\section{The Couvade}

Is the recently published September issue of FolkLore, Mr. L. F. Newman discusses the curious but widespread and ancient custom named couvade', which consists in the illness of the husband during his wife's pregnancy, parturition and puerperium.
He classifies the theories as to its origin in three groups according as they are held by (1) the classical school, who follow Apollonius Rhodius, Strabo, Plutarch and the other early writers; (2) the historians, who base their views on authors such as Marco Polo, Bacon, Butler and others; and (3) the anthropologists, who are influenced mainly by scientific data and records from the life of the more primitive peoples. Mr. Newman comes to the conclusion that a number of quite diverse customs have been grouped together under the name of the 'couvade', and that many are not different types of one definite custom, but are survivals of recorded instances of separate eustoms and are of multiple origin.

\section{Standardizing Electrical Instruments}

IN a paper read on December 3 in London before the Institution of Electrical Engineers, Lieut.-Col. K. Edgcumbe dealt with the standardization of industrial electrical instruments from the aspects of performance limits, dimensional limits and certain constructional features facilitating interchangeability and promoting commercial manufacture, and other minor matters such as preferred terms, definitions, symbols, etc. Comparisons are made of the standards issued in Great Britain, the United States and Germany and by the International Electrotechnical Commission, suggestions being put forward for the extension or amendment of the pertinent specifications issued by the British Standards Institution, notably BS81, $B S 89$ and $B S 90$.

\section{Announcements}

WE regret to announce the death of Sir Henry Miers, F.R.S., Waynflete professor of mineralogy in the University of Oxford during 1895-1908, principal of the University of London from 1908 until 1915, and vice-chaneellor of the University of Manchester and professor of crystallography during 1915-26, on December 10, aged eighty-four.

DR. G. A. R. Kow has been appointed as the first occupant of the University of London chair of chemistry tenable at the Royal Cancer Hospital (Free), which was instituted just before the outbreak of war. Dr. Kon has been a member of the staff of the Imperial College of Science and Technology since 1925 , the title of reader in organic chemistry being conferred on him in 1935 .

IT is announced that the estate of Sir Joseph Larmor, who died on May 19 (see Nature, June 6, p. 631), amounts to $£ 54,500$. He made the following bequests, among others : $£ 3,000$ to St. John's College, Cambridge, for annual rewards for undergraduates; $£ 3,000$ to the Royal Academical Institution, Belfast, to supplement scholarships; $£ 3,000$ to augment emoluments held by junior members in Northern Ireland of Queen's University, Belfast; $£ 2,000$ to the University of Cambridge to provide medical and other assistance to junior members of the University ; $£ 1,000$ each to St. John's College, Cambridge, and Magee University College, Londonderry; and £750 each to Trinity College, Dublin, and the National University of Ireland for the benefit of University College, Galway. Subject to other bequests, the residue is to be used for increasing the educational bequests to St. John's College, Cambridge, the Royal Belfast Academical Institution, and Queen's University, Belfast. 